\title{
Společenské faktory utvářející rámec pro uchopení role babičky. Reflexe babiček z Pardubic a okolí
}

\author{
TEREZA ČEPILOVÁ*
}

Social Factors Forming the Basic Framework for Prehension of the Role of a Grandmother. Reflections of Grandmothers from Pardubice and Surroundings

\begin{abstract}
The aim of this article is to describe the social aspects that affect performing the role of grandmother. The historical-sociological approach was chosen to research this topic. It uses knowledge of previous situations and processes to an in-depth understanding of the contemporary situation. Interviews realized with eight grandmothers of children aged 6-8 were analyzed. The article presents the grandmothers' reflection of the social framework for performing the grandmother's role. In grandmothers' opinions, this framework has a significant impact on the possibilities of performing a grandmother's role. Using the historical-sociological approach also allowed us to identify changes in the framework during the last decades. These changes are explained on examples of the last three generations of grandmothers in the text.
\end{abstract}

Keywords: grandmothers; grandparents; family role; historical-sociological approach

DOI: $10.14712 / 23363525.2021 .7$

\section{Úvod: Význam časového a prostorového ukotvení role babičky}

V české a zahraniční literatuře lze vysledovat několik obecně přijímaných faktorů, které prarodičovskou roli utvářejí. V prvé řadě se jedná o pohlaví (gender) prarodiče, které ovlivňuje jak konkrétní naplňování prarodičovské role z hlediska babiček a dědečků [např. Vidovićová - Galčanová - Petrová Kafková 2015], tak i odlišné vnímání obou prarodičovských rolí ze strany vnoučat [např. Bhopal - Brannen - Heptinstall 2000]. Dále odborné studie hovoří o vlivu rodinné linie, a to např́íklad na četnost kontaktu vnoučat a prarodičů z matčiny a z otcovy rodinné linie [např. Kahana - Kahana 1970]. Konkrétní naplňování role prarodiče se liší i osobním př́stupem utvářeným základními charakteristikami prarodiče a jeho zájmy, $\mathrm{k}$ čemuž podle výzkumníků přispívá i absence jednotné představy o této roli [např. Hasmanová Marhánková 2015; Gauthier 2002]. Rodinná situace a vztahy na úrovni nukleární i širší rodiny mohou být dalším významným faktorem, který se do vykonávání prarodičovské role promítá [Kemp 2007; Davies 2011; Gauthier 2002]. Uchopení role prarodiče je podle výzkumníků ovlivněno také věkem vnoučete, jemuž musí být pojetí role v průběhu času přizpo̊sobováno [např. Hurme - Westerback - Quandrello 2010; Kahana - Kahana 1970]. Z dosud provedených výzkumů vyplývá, že vykonávání role prarodiče je ovlivněno i geografickou vzdáleností mezi místem bydlišš̌ vnoučete a místem bydliště prarodiče [např. Hasmanová Marhánková - Štípková 2014; Quadrello et al. 2005]. $\mathrm{Z}$ tohoto stručného přehledu faktorů ovlivňujících vykonávání role prarodiče, o nichž se

\footnotetext{
* Mgr. Tereza Čepilová, Fakulta humanitních studií, Univerzita Karlova, Pátkova 2137/5, 18200 Praha-Libeň. E-mail: t.cepilova@seznam.cz
} 
v souvislosti s danou rolí často hovoří a s kterými se ve výzkumech pracuje, by se mohlo zdát, že prarodičovská role je do značné míry ovlivněna kromě určitých daností (např. rodinná linie) především charakteristikami konkrétního prarodiče a jeho specifickými rodinnými konstelacemi. Značná závislost určitého pojetí prarodičovské role na konkrétních jedincích a jejich rodinných vztazích, a z nich vyplývající mnohost takovýchto pojetí, by byla v souladu s absencí jednotné představy o prarodičovské roli [např. Hasmanová Marhánková 2015]. Také tvrzení českého sociologa Lukáše Urbana, který hovoří o tom, že v intimnějších oblastech světa člověka nalézáme poněkud rozvolněnější rolové předpisy [Urban 2011], by odpovídalo existenci různých pojetí prarodičovské role.

Jak ovšem upozorňuje americký sociolog Peter Uhlenberg [2004], vnímání role prarodičů a charakter vztahu mezi prarodiči a vnoučaty je nutné vnímat i v určitém širším časovém a geografickém měřítku. Mnoha studiím k tématu prarodičovství však podle $\mathrm{P}$. Uhlenberga časový a prostorový kontext chybí. Závěry výzkumů je přitom nutné do určitého kontextu zasazovat, nebot', jak ukazují některé realizované výzkumy, rozdíly ve vnímání a vykonávání role prarodiče se liší místně [Harper - Smith - Hagestad 2010; Sandel et al. 2006; Souralová 2015] i časově [Gauthier 2002; Gratton - Haber 1996; Cherlin - Furstenberg 1986]. Společnost tudíž rámcově nastavuje určité možnosti a mantinely, v rámci nichž pak mohou existovat různá více či méně odlišná pojetí vykonávání prarodičovské role.

Jako př́iklad geografických odlišností prarodičovské role lze uvést studii amerických výzkumníků Todda L. Sandela, Grace E. Choové, Peggy J. Millerové a Su-hua Wangové [2006] zabývající se euroamerickými a tchajwanskými babičkami. Zatímco tchajwanské babičky zastávají během předškolního věku dítěte pečovatelskou funkci a zabezpečují všechny primární potřeby dítěte, euroamerické babičky se ocitají spíše v roli společníka či kamaráda a v př́padě potřeby jsou připraveny pomoci. Jiní výzkumníci poukazují v souvislosti s geograficky odlišnými pojetími role prarodiče na skutečnost, že očekávané kulturní rozdíly se nemusejí u zkoumaného vzorku projevit, pokud lidé žijí v jiném kulturním prostředí než je jejich původní [Bhopal - Brannen - Heptinstall 2000: 136].

Pro předkládanou studii je ovšem podstatnější druhý Peterem Uhlenbergem zmiňovaný aspekt, kterým je časový kontext konkrétních výzkumů a prezentovaných studií. Jako příklad historických proměn prarodičovské role lze v hrubých rysech načrtnout změny, kterými prošla role amerických prarodičů. Podle amerických historiků Briana Grattona a Carole Haberové [1996] byli zhruba do poloviny 19. století prarodiče vnímáni jako autorita, která spolu s úctou ke starým lidem plynula $\mathrm{z}$ ekonomických pout. Prarodiče měli jako vlastníci půdy ekonomickou a sociální kontrolu nad mladšími generacemi, které na nich finančně závisely. Poté podryla autoritu prarodičů jako držitelů půdy industrializace. Narůstala nezávislost dospělých dětí a jejich potřeba oddělených domácností. Starý věk začal být vnímán jako tíživé a neproduktivní období spojené s nemocemi. Prarodiče byli vnímáni jako př́iěž a ohrožení pro rodinu [Gratton, Haber 1996: 7-9].

Vrstva nezávislých důchodců vznikala zhruba od 50. let, kdy podle amerických historiků a sociologů přineslo rozšíření sociálního systému lepší zajištění seniorů [Uhlenberg 2004: 92; Gratton - Haber 1996: 10; Cherlin - Furstenberg 1986: 32]. Tito lidé již podle B. Grattona a C. Haberové [1996: 11] nezastávali významnou ekonomickou roli v rámci rodiny, ale zároveň pro rodinu nepředstavovali hrozbu. Požadavky úcty a poslušnosti a emocionální odstup starších generací prarodičů a vnoučat byly v poválečném období postupně nahrazovány důrazem na lásku a náklonnost a prarodiče se stali společníky 
vnoučat [Gratton - Haber 1996: 11; Cherlin - Furstenberg 1986: 35]. Kulturní vzorec prarodičovství je v dnešní době podle P. Uhlenberga [2004: 93] pozitivnější a zdůrazňuje lásku a emocionální blízkost vnoučat a jejich prarodičů.

Vliv na roli prarodiče měly v průběhu 20. století i demografické faktory. Pokles úmrtnosti způsobil, že děti dnes mají více prarodičů a častěji je zažijí i v době své dospělosti [Uhlenberg 2004: 82; Cherlin - Furstenberg 1986: 25]. Pokles porodnosti vedl k tomu, že téměř vymizel souběh rodičovství a prarodičovství, v důsledku čehož mají prarodiče méně rodinných rolí [Cherlin - Furstenberg 1986: 28]. Děti také mají méně sourozenců a bratranců či sestřenic, se kterými by soupeřily o pozornost a zdroje prarodičů [Uhlenberg 2004: 85]. Celkově vzato, proměny role prarodičů během 20. století podle Petera Uhlenberga zapříčinily, že dnes mají prarodiče pro děti větší význam, než tomu bývalo dříve [Uhlenberg 2004: 77].

$\mathrm{V}$ českém prostředí se proměně obsahu role babičky okrajově v jednom ze svých článků dotýká socioložka Jaroslava Hasmanová Marhánková [2015]. Co se týče vztahu babiček a vnoučat, podobně, jako již bylo zmíněno výše u prací amerických sociologů a historiků, i J. Hasmanová Marhánková zaznamenala v českém prostředí proměnu citového vztahu. Respondentky jejího výzkumu, současné babičky, hodnotily své babičky jako poměrně vzdálené postavy, s nimiž nenavázaly žádný hlubší osobnější vztah. Generace babiček současných matek, další skupiny respondentek, již byla mnohem důležitější součástí rodinných vztahů a přibylo společně tráveného času babiček s vnoučaty [Hasmanová Marhánková 2015: 753].

Dále respondentky podle J. Hasmanové Marhánkové často poukazovaly na vyšší nároky, které jsou na dnešní babičky kladeny. Zatímco dřívější babičky se soustředily na péči, dnešní babičky musí kombinovat péči spolu se svým pracovním životem. Současné babičky byly dotazovanými matkami popisovány jako ženy soustředěné na budování vztahu s vnoučaty a zajištující vnoučatům zábavu, přičemž se věnovaly i svým pracovním povinnostem. Proměnu naplňování role babičky dává J. Hasmanová Marhánková do souvislosti se změnou ve vnímání stáří jako období pasivity. Výrazným rámcem současné prarodičovské generace je podle ní norma aktivity. Zdůrazňovány jsou podle J. Hasmanové Marhánkové prodlužující se pracovní biografie a aktivní životní styl seniorů [Hasmanová Marhánková 2015: 753-755].

Z výše uvedených příkladů lze vidět, že podoba a naplnění role prarodičů se liší v různých historických obdobích a odvíjí se od demografických změn, míry technologického pokroku, úrovně dostupné zdravotní péče, kulturního obrazu stáří i od ekonomického fungování společnosti v daném období. Škála společenských faktorů, které nezávisle na jednotlivcích utvářejí rámec a vymezení pro konkrétní uchopení prarodičovské role a způsoby jejího vykonávání, je dosti široká.

Tento text bude zaměřen na společenské faktory spoluutvářející podobu babičkovské role s vědomím, že roli babičky utvářejí také individuální biografie ženy, její životní zkušenosti, rodinné vztahy i individuální charakteristiky jejího vnoučete. Společenské faktory zde budou chápány jako klíč utvářející v čase relativně stabilní, nikoliv však zcela neměnný rámec pro aktuální vykonávání babičkovské role. S přihlédnutím k sociologickému vymezení sociální role Lukášem Urbanem [2011: 167] bude ve studii přistoupeno k roli babičky jako k určitému celku očekávaného chování, jednání a činností, které vyplývají ze specifické pozice ženy v rámci rodiny. Cílem textu je zodpovědět, jaké společenské faktory 
utvářející rámec pro individuální uchopení role babičky reflektují současné babičky a jaké dopady na prarodičovskou roli podle nich tyto faktory v průběhu posledních desetiletí měly. Oproti většině současných výzkumů zkoumajících roli babičky v kontextu nastavení soudobého společenského rámce daný text využije paměti a vzpomínky dotazovaných žen, které se týkají posledních tři generací babiček. Jako nositelky babičkovské role mohly dotazované ženy vnímat stabilitu i proměny společenského rámce vymezujícího roli babičky zhruba od poloviny 20. století. Z reflexe babičkovské role objevující se ve třech posledních generacích snáze vystoupí společenské faktory a jejich proměny, které jsou podle dotazovaných žen pro vykonávání jejich vlastní babičkovské role významné.

\section{Participantky a výzkumná data}

Předkládaná mikrostudie je prvním výstupem širšího třígeneračního výzkumu zaměřeného na obraz a proměny role babičky během posledních tř́i generací. Vzhledem $\mathrm{k}$ šíři výzkumného záměru a dosavadním odborným poznatkům o odlišnostech mezi rolí babiček a dědečků byl výzkum zaměřen pouze na roli babičky, což umožnilo hlubší porozumění babičkovské roli, která dosud není v českém prostředí příliš detailně prozkoumána. Složení výzkumného vzorku, na němž je tato mikrostudie založena, se odvíjelo od nejmladší dotazované generace. Žáci 1. tříd tř́i základních škol v Pardubicích byli osloveni v rámci školního vyučování, aby se zapojili spolu se svými rodiči a babičkami do připravovaného výzkumu. Každý z žáků dostal pro své rodiče a babičky informační leták spolu s informovaným souhlasem.

Tabulka 1: Charakteristika participantek

\begin{tabular}{|l|c|c|c|c|c|c|c|}
\hline Jméno & $\begin{array}{c}\text { Rok } \\
\text { naro- } \\
\text { zení }\end{array}$ & $\begin{array}{c}\text { Ekono- } \\
\text { mický } \\
\text { stav }\end{array}$ & $\begin{array}{c}\text { Rodinný } \\
\text { stav }\end{array}$ & $\begin{array}{c}\text { Počet } \\
\text { dětí }\end{array}$ & $\begin{array}{c}\text { Počet } \\
\text { vnoučat }\end{array}$ & Bydliště & $\begin{array}{c}\text { Bydliště do- } \\
\text { tazovaného } \\
\text { vnoučete }\end{array}$ \\
\hline Jana & 1969 & pracuje & vdaná & 2 & $\begin{array}{c}1+1 \\
\text { nevlastní }\end{array}$ & Pardubice & Pardubice \\
\hline Anna & 1946 & v důchodu & vdaná & 4 & 8 & $\begin{array}{c}\text { Obec } \\
\text { u Chlumce } \\
\text { nad Cidlinou }\end{array}$ & Pardubice \\
\hline Jaroslava & 1942 & v důchodu & $\begin{array}{c}\text { bez } \\
\text { partnera }\end{array}$ & 2 & 4 & Pardubice & Pardubice \\
\hline Hana & 1959 & pracuje & partner & 2 & $1+1$ & Pardubice & Pardubice \\
\hline Alena & 1952 & v důchodu & vdaná & 4 & 6 & Chrudim & Pardubice \\
\hline Růžena & 1939 & v důchodu & vdova & 2 & 3 & $\begin{array}{c}\text { Obec } \\
\text { u Pardubic }\end{array}$ & Pardubice \\
\hline Věra & 1947 & v důchodu & vdaná & 2 & 4 & Pardubice & Obec \\
\hline Marie & 1951 & v důchodu & vdaná & 2 & 6 & $\begin{array}{c}\text { Hradec } \\
\text { Králové }\end{array}$ & Pardubice \\
\hline
\end{tabular}


Mikrostudie zpracovává rozhovory s osmi ženami, které měly osobní zkušenost s babičkovskou rolí. Dotazované ženy (babičky), které se výzkumu účastnily, se narodily v letech 1939, 1942, 1946, 1947, 1951, 1952, 1959, 1969. Dvě z žen byly stále ekonomicky aktivní, z toho jedna z nich byla rozvedená a měla nový partnerský vztah, druhá žila v domácnosti s manželem. Šest žen již bylo v důchodu, dvě z nich žily v domácnosti bez partnera, jedna zcela sama, druhá s rodinou své dcery. Šest žen mělo dvě děti, dvě ženy měly čtyři děti. Dvě ženy se čtyřmi dětmi měly šest a osm vnoučat, další dvě ženy měly jedno vlastní a jedno nevlastní vnouče, jedna žena měla tři vnoučata, další dvě ženy měly čtyři vnoučata a jedna žena byla babičkou šesti vnoučat.

Zvolený způsob tvorby vzorku s sebou nese jisté limity týkající se jeho složení. Do výzkumu se nezapojila žádná žena, která by se se svou babičkovskou rolí neztotožňovala nebo by ji vnímala jako okrajovou. Stejně tak se do výzkumu nezapojily babičky, které sice přistupují aktivně ke své babičkovské roli, ale byly např. vlivem pracovních povinností časově vytížené. Otázkou však je, zda by se reflexe společenského rámce u těchto žen něčím výrazně odlišovala od názoru dotazovaných žen, nebot ty rovněž reflektovaly např. pracovní vytížení současných babiček nebo jejich volnočasové zájmy.

Hloubkové rozhovory realizované s ženami trvaly v průměru 80 minut a pokryly témata dětství žen a jejich tehdejších rodinných a příbuzenských vztahů, zapojení rodičů dotazovaných žen do péče o vnoučata, dále se dotýkaly jejich vlastních vnoučat a současných příbuzenských vztahů a v hrubých obrysech zmapovaly rozhovory i osobní a pracovní život dotazovaných žen. Analýza dat byla inspirována principy interpretativní fenomenologické analýzy [Koutná Kostínková - Čermák 2013] a využila osobní zkušenosti dotazovaných žen jako nositelek babičkovské role k pochopení toho, jakými faktory je ovlivňována podoba vykonávání role babičky. Jednotlivé přepisy rozhovorů byly nejprve opoznámkovány a poté byla formulována tzv. rodící se témata. Vzhledem k tematickému záběru rozhovorů (součást širšího výzkumu) byly v této fázi analýzy poznámky a komentáře přiřazeny k jednomu ze tři sledovaných období v životě dotazovaných žen (dětství, rané mateřství, babičkovství). Takto bylo postupováno jednotlivě u každého případu. Poté byl na základě rodících se témat a v závislosti na výzkumných otázkách propracován finální seznam témat a podtémat, který byl identický pro všechna tři sledovaná období. Následně probíhalo srovnávání jednotlivých př́padů a hledání podobností a vzorců mezi nimi.

\section{Společenské faktory utvářející rámec pro uchopení babičkovské role}

Z rozhovorů s dotazovanými ženami vyplynulo, že role babičky je ovlivněna obecným charakterem společnosti: ekonomickou aktivitou obyvatelstva, dopravní infrastrukturou, úrovní vědeckého poznání, stupněm technologického rozvoje nebo společenskými náladami. Vykonávání role babičky proto nabývá v různých historických obdobích specifických rysů. Jak uvedla paní Růžena (1939): Ty babičky jsou taky jiný, takový jako že ten prostě způsob života a ta doba... že jsme někde jinde, takže to je jako jiný. (...) asi je rozdíl, jak se i třeba chovaly nebo oblikaly nebo vyjadřovaly dř́v než dneska. Přináší to ten jako pokrok. Dopady působení jednotlivých celospolečenských faktorů na roli babičky se v průběhu času mění - některé se proměňují ku prospěchu role babičky, jiné ji činí obtížněji vykonavatelnou. 


\section{Pracovní povinnosti: Život naplněný prací}

Jako jeden z výrazných společenských faktorů, který podle dotazovaných žen ovlivňuje vykonávání role babičky, jsou pracovní povinnosti ženy, resp. různé způsoby přispívání žen k zajištění obživy rodiny.

Dotazované ženy uváděly, že jejich babičky většinou nepracovaly a neměly klasické zaměstnání v dnešním slova smyslu. Například paní Alena (1952) ve svém vyprávění zmínila, že její babička měla za mlada přivýdělek v podobě vyšívání: Tak moje babička vlastně, pocházeli z velmi chudýho kraje, (...) mèli malý políčko a děda chodil pracovat do lomu. Babička vlastně, jak to bejvalo, byla doma a když byla mladá, tak vyšívala vlastně a tím se tak nějak jako... si přivydělávala. Část ženami vzpomínaných babiček žila na vesnici. Dotazované ženy vzpomínaly, že s vesnickým životem bývalo spojeno obdělávání většího či menšího pole a chování drobných nebo hospodářských zvířat. Pole a zvírata přinášela lidem obživu a povinnosti kolem hospodářství zaplnily lidem většinu dne. Venkovský život ilustruje vzpomínka paní Jaroslavy (1942), reprezentující skupinu žen, která v dětství žila spolu s babičkou nebo v její bezprostřední blízkosti: (...) dědeček a babička, tak měli život naplněný prací, od božího rána do božího večera, a to trvalo celou sezónu, to znamená jaro, léto, podzim. Akorát v zimě měli nějaký čas, kdy si od tohohle odpočinuli a kdy ale taky pracovali, třeba zašívali pytle na obilí nebo drali peří, nebo opravovali všelijaké věci (...), takže kde tam byl čas pro nás pro dèti. Co já si pamatuju, takže samozřejmě byla babička furt na poli a musela $i$ vařit. Zmiňovaným babičkám neotevírala práce „doma“, v domácnosti, na hospodářství nebo na poli velký prostor pro hraní a zábavu s vnoučaty. Děti si ovšem mohly na vesnici hrát s ostatními dětmi a v př́padě, že by se něco přihodilo, babička jim byla nablízku k dispozici radou nebo pomocí.

Ostatní babičky dotazovaných žen nežily v blízkosti svých vnoučat a do každodenní nebo časté péče o ně zapojeny nebyly. Podle dotazovaných žen péči o děti dokázaly jejich matky v zásadě pokrýt samy, př́padně jim vypomáhaly nejstarší děti, jako tomu bylo např́klad u paní Aleny (1952). Jedinou participantkou výzkumu, která nepoznala své babičky, byla paní Věra. Veškerou péči o ni a její sourozence zastala sama její matka. Situace paní Věry podle jejích vzpomínek nebyla ve své době ojedinělá: Opravdu, co jsem měla jako okolo, nás bylo tehdá ve třídè, protože to byl ten 47. ročník, poválečný ročníky, tak nás bylo 41 ve tř́dě, no. Ale řekla bych, že snad ani polovička neměla babičku ani dědu, abych pravdu řekla, protože dost ve válce jako to zemřelo.

Zaměstnané ženy se v rodinách dotazovaných žen objevily až s generací jejich matek, které začaly v poválečném období docházet do zaměstnání. Válečný i generační přelom v zaměstnanosti žen dokládá vyprávění paní Růženy (1939): Měli to holičství (pozn. babička a děda), ted’ pole měla (...), samozrejmě že do práce jako nechodila, to nebylo tak běžný, že jo, to bylo až po tý válce, že jo, třeba maminka a tak, no. Pomoc s péćí o děti probíhala u dotazovaných žen odlišně. Např́iklad paní Růženě (1939) a paní Věře (1947) pomáhaly s péčí o děti jejich matky. U paní Věry vypomáhala její matka několikrát do týdne: Ona bych řekla, když byly děcka, tak dvakrát za týden byla u nás určitě a někdy i na víkendy. Paní Anna (1946) vzpomínala, že jí matka s péčí o děti moc nepomáhala: Mamka jako moc hlídat nechtěla a ted' ji chápu, protože někdy mě to taky unavuje už a to, ale ono hlídat v̌̌echny děti... tak je pohlídala, $k d y \check{z}$ jsem potřebovala $k$ zubaři nebo $k$ doktorovi, to jo. U prvních 
dvou dětí paní Anně pomáhala s hlídáním její babička. Paní Haně (1959) pomáhala s péčí o děti také její nevlastní babička, která však byla věkově blíže matce paní Hany spíše než její babičce. V dobrém vzpomínala paní Hana i na pomoc tchyně a tchána z prvního manželství, které skončilo předčasnou smrtí jejího manžela. Paní Jaroslavě (1943), jejíž rodiče, stejně jako manželovi rodiče, bydleli daleko, s hlídáním vypomáhala paní na hlídání, ze které se $\mathrm{v}$ podstatě stala náhradní babička. Paní Jaroslava byla primářkou v nemocnici a bez výpomoci s péčí o děti by se podle svých slov neobešla.

Pro generaci dotazovaných žen už bylo zaměstnání běžnou součástí života. Oproti generaci svých matek však poukazovaly dotazované ženy na prodloužení věku odchodu do důchodu, které jim podle jejich názoru vykonávání prarodičovské role znesnadňovalo. Paní Hana (1959) ani paní Jana (1969), které byly obě stále ekonomicky aktivní, nebyly spokojené s množstvím času, který na svá vnoučata měly. Přály by si věnovat se vnoučatům mnohem více. Paní Jana (1969) uvedla: A říkám, čím dál víc (smích), že kdyby byl starej režim, co byl, tak bych vlastně za dva roky šla do di̊chodu. Ǩíkám, to bych si tak užívala. Takhle ještě dalších skoro deset let. (...) No, když to jde, tak se snažím si urvat ten čas, no. Ostatní dotazované ženy už ekonomicky aktivní nebyly a zároveň měly více vnoučat. Tyto ženy hovořily o tom, že si vnoučata narozená až v době, kdy už byly v důchodu, mohou více užívat, protože na ně mají dostatek času. Paní Anna (1946), která měla osm vnoučat, vzpomínala: První... ne, to jsem ještě nebyla, já jsem šla do důchodu 2004, (...) a tyhlety (pozn. vnoučata) až byly $v$ dưchodu, takže ty si můžu víc užít, protože ono na ty směny to bylo náročný.

\section{Odkládání rodičovství: Méně sil a energie}

Paní Hana (1959) během rozhovoru poukázala na to, že posunutí věku odchodu do důchodu, zmiňované výše, je doprovázeno současným fenoménem odkládání rodičovství do vyššího věku. Dříve měly podle paní Hany mladé ženy děti v dřivějším věku, takže babičky na tom bývaly, co se ekonomické aktivity týče, podobně: Ale zase za mých rodiču, kdy byli rodiče (pozn. prarodiči) třeba ve 44, taky chodili až za 10 let, v 55, že jo, takže jsme to měli prakticky nastejno, jo. Dneska ty maminky jsou starší, třeba už těch 27 (...). Zároveň ale zásadní rozdíl dotazované ženy spatřovaly ve věku, kdy se ženy stávají babičkami. Předchozí generaci babiček podle nich bylo výrazně méně let než současné generaci babiček a měly tak podstatně více fyzických sil, stejně jako rodiče dětí. Paní Hana (1959) uvedla: Akorát je pravda, že ty naši rodičové nebo rodiče měli prostě víc síly a energie. Když tedkka jdete v 61 (pozn. do důchodu), tak už to prostě tak není. Paní Věra k problému dodala: (...) každej má co nejdýl děti. Já z vlastních zkušeností, že jsem měla starý rodiče, jo, tak jsem ř́kala: „Vy jste normálně nezodpovědný, doslova a do písmene. “Protože, je fakt, že dneska je životnost větší, že se doživaj ty lidi to, ale at mi nikdo neříká, že ve 40 letech dám tomu dítěti tolik jako v 25, když jsem fyzicky na tom podstatně lepší. Dotazované ženy ve svých vyprávěních vycházely ze zkušeností z vlastních rodin, které se ovšem, co se týče věku, kdy se ženy stávaly a stávají matkami, lišily. Přesto byla reflexe odkládání rodičovství do vyššího věku spojená s úbytkem sil rodičů i prarodičů v jejich vyprávěních čitelná. 


\section{Zaměstnání matek: Vzít si ošetřovačku je problém}

Vykonávání babičkovské role je podle dotazovaných žen ovlivněno i zaměstnáním matek jejich vnoučat. Oproti dřivější generaci jsou podle dotazovaných žen současné matky v horší situaci, co se týče kombinování ekonomické aktivity a péče o děti. Např́iklad v době nemoci dítěte je podle názoru dotazovaných žen často problematické zůstat s dítětem doma kvưli obavám o ztrátu zaměstnání. Tuto situaci prý nynější generace babiček nezažila. Paní Hana (1959) popsala rozdíl takto: (...) vzít si neschopenku nebo ošetřovačku je problém, protože co když je vyhodí z práce. Za nás to nebylo. My jsme vopravdu... já jsem měla obě dvě děti dost nemocný, rýma, kašel, šla jsem prostě na týden na ošetřovačku. Dneska se bojíte, aby vás nevyhodili. Paní Hana (1959) zmiňovala i rozrůznění pracovní doby, která podle ní dříve bývala jasně daná: Třeba pracovní doba za našich rodičủ byla přesně daná. Třeba od šesti do dvou. Kdežto ted', já třeba ráno vyjedu v pět (...) a vrátím se večer $v$ šest. A potom si už teda musím jít lehnout. Paní Věra (1947) popisovala pracovní dobu své dcery takto: Monika má blbou pracovní dobu, že jo, takže se dá ř́ct minimálně 4 dny v týdnu jsme vyzvedávali ze školky jednu, pak druhou, no a pak ze školy jednu, pak druhou. Specifickým př́padem jsou v dnešní době podle paní Hany (1959) podnikatelé, jimž pracovní doba v podstatě přes den vůbec nekončí: (...) co teda týdlectý generaci nezávidím, že chodí od rána do večera do práce, spousta podnikatelù na děti svý nemaj čas, fakt nemaj. Pokud tedy dotazované ženy mohly, snažily se matkám svých vnoučat s péčí o děti vypomáhat, at už v době nemoci nebo občasným či téměř každodenním voděním dítěte do školky či školy nebo jeho vyzvedáváním. Např́íklad paní Jaroslava (1942) uvedla: Tak kdyby ta moje holka furt pracovala, jako když pracovala, tak jsem musela jí pomáhat. Bez toho to nebylo možné, odvézt dítě, když měla jenom tu první holčičku tř́letou. Když se rozvedla (...), takže chodila do práce, a já jsem jí denně vodila do školy, do školky, potom do školy, než začala chodit sama. Máma chodila do práce. Často jsem pro ní šla ze školy, chodila jinak do družiny (...). Já jsem pracovala na částečný úvazek tehdá ještě, takže jsme to musely nějak pytlikkovat, ale ráno jsem vždycky měla čas pro ni, takže jsem ji vodila. (...) No, asi to trvalo pět rokü, tohleto. Výpomoc dnešních babiček s vyzvedáváním dětí ze školy dnes není ničím ojedinělým. Jak uvedla paní Věra (1947): (...) když my přicházíme pro Petru nebo přijíždíme, tak sem tam nějakej rodič, ale spiš prìižžděj babičky (...).

\section{Časová vytíženost: Stihnout všechno možné i nemožné}

Dotazované ženy v souvislosti se změnami role babičky často zmiňovaly nedostatek času, který na svá vnoučata měly. Způsobený byl několika odlišnými příčinami. Kromě pracovních povinností, které již byly představeny výše, se jednalo o péči o rodinné příslušníky, starost o domácnost a osobní aktivity babiček. V rozhovorech ovšem ženy upozorňovaly i na skutečnost, že jejich vykonávání role je omezeno i časovým zaneprázdněním na straně vnoučete.

Péče o rodinné příslušníky zahrnovala $\mathrm{v}$ případech dotazovaných žen kromě vnoučat i vlastní rodiče nebo sourozence. Péče ženy pak musela být určitým způsobem dělena mezi všechny potřebné. Paní Růžena (1939), která žila sama v domě, hovořila o žádosti o pomoc od svých sester takto: Moje dvě sestry, ty zas by si představovaly, že já bych mohla se o ně starat. (...) Mně bude v srpnu 78. (...) Mám je ráda (...). Dobrý, ale já říkám: „Děvčata, už 
jsem taky stará. "Víte, ted’ taky mám ještě tu vnučku sedmiletou (...), no, tak víte, taky ty dèti taky si chci užit dokud’ to jde, dokud' můžu a tak dále. (...) já jsem ř́ikala, jo, jdu tam nebo takhle když (...) potřebovala, tak nemůžu říct, že bych jí neudělala, to ne, ale nedá se nic dělat, mám toho sama dost, opravdu. Paní Hana hovořila o tom, že v dnešní společnosti je v podstatě o jednu generaci navíc. Tato generace pak může, stejně jako v případě paní Hany, svou potřebou péče vstupovat do už tak naplněného denního rozvrhu současných prarodičů: (...) tady je vlastně o jednu generaci navíc. Tady je spousta devadesátiletejch, stoletejch, přes 80 rokü. (...) moje babička i děda zemřeli 68 rokü, takže mamce bylo přes 40 a ty rodiče už neměla. Mně už bude 60 a ty rodiče mám. Jo, takže... ještě je práce, vnoučata, domácnost a ještě... vlastně ted' nevíte, ke komu se máte víc starat. Jestli teda nemocný rodiče, nebo teda jít $k$ vnoučeti.

V menší míře zabíraly část času dotazovaným ženám i jejich zájmy či jiné společenské aktivity. Paní Růžena (1939) hovořila o tom, že dnešní babičky si chtějí užívat a věnovat se i svým zájmům nebo cestování: To taky dneska ty babičky jsou takový jako... takový moderní, zaprvé, a chtěji si taky ještě zas ty léta užit. Pokud můžou, že jo. Přesto se mezi dotazovanými ženami neobjevila žádná, která by byla svými volnočasovými aktivitami významně časově vytížená, nebo kterou by tyto aktivity nějakým způsobem omezovaly v možnosti pečovat o vnoučata. Povětšinou se u dotazovaných žen jednalo o nějaké opakující se organizované aktivity (např. kurzy šití, návštěva kurzů univerzity třetího věku) nebo o společenská setkání typu školního srazu jako u paní Růženy (1939): Ted’ jsem měla sraz taky z tý obchodní školy, to víte, my už jsme báby a bylo nás asi 12, ale vždycky od začátku jsme se scházely.

Dotazované ženy však poukazovaly na to, že příležitostí ke společnému trávení času babiček a vnoučat ubývá i v důsledku proměn na druhé straně tohoto vztahu, na straně vnoučete. Např́klad paní Věra uvedla: To oni: „Tamhle musím bejt, támhle musím bejt“ a chtěj stihnout všechno možný i nemožný teda. Paní Růžena (1939) k vytížení dnešních dětí dodala: (...) maj těch novinek a všecko, že ty děti už... tolik času třeba ani na to nezbývá. Nebo ty děti jsou už dneska takový jako využitý po všech směrech, že jo. Podle dotazovaných žen byly děti hodně časově vytížené, mj. i různými zájmovými kroužky nebo sportovními kroužky. S těmi souvisely také různé zápasy a turnaje, kterých se vnoučata účastnila o víkendech. Ani ve dnech, kdy vnoučata neměla školu, tedy neměla pokaždé čas na to, aby se jela podívat za babičkou, případně aby babička mohla přijet za nimi. Situaci ohledně setkávání s vnoučaty popsala paní Marie (1951): (...) jsou všichni tak vytížený, i ty vnoučata jsou vytížený, mají různý kroužky a takový, že jo. (...) taky maj jako zájmy, ona ta vnučka hraje fotbal, jo, takže maj různý zápasy, pak ještě, já nevím, jestli chodí hrát, myslím, na piáno. Ten Honza chodí... jo, a ten beach volejbal choděj oba. No, takže prostě... a já říkám třeba: „Tak přijedte, “ nebo tak. A oni: „No, to my, babi, nemüžem, protože máme turnaj nebo máme zápas, “jo (...).

\section{Strach o děti: Úzkostliví rodiče}

Ve vyprávěních dotazovaných žen se mezi faktory, které ovlivňují roli babičky, objevoval také pocit strachu o děti. $Z$ drrívějších dob si dotazované ženy podobnou atmosféru ve společnosti nevybavovaly a výrazný strach o děti se podle nich objevil až s generací jejich vnoučat. Děti se podle vzpomínek dotazovaných žen pohybovaly venku volně, typické to 
bylo zejména pro venkovské prostředí, a trávily volný čas v dětském kolektivu. Ženy starající se o hospodářství fungovaly jako záloha. Byly pobližz, kdyby děti něco potřebovaly. Paní Rủžena (1939) srovnávala dobu svého mládí a dobu svých vnoučat a vnímala přitom značný rozdíl ve snaze zajistit dětem bezpečí při jejich pohybu venku: Zas dř́v jsme běhali, lítali, kor na vesnici nebo i $v$ sídlišti, a dneska se spiš jako taky o ty děti, vidím, bojej. To není žádná legrace, (...) dneska jezděj autem pro děti (...). Paní Alena (1952) vzpomínala na volnost, kterou zažívala o prázdninách u své babičky: (...) vlastně byla to vesnice, kamarádili jsme tam s těma vesnickejma dětma a měli jsme tam volnost. (...) myslím si, že ty děti to potřebujou, že dneska to je takový hodně utažený (...). Taky a ta doba byla bezpečná. (...) Neř́kám, že si rodiče o nás nedělali starost, ale asi nebyli tak úzkostliví (...). Dotazované ženy, které vyrůstaly ve městě, hovořily o tom, že také na městských sídlištích byl v domech vždy v záloze někdo, soused nebo ženy, které stále ještě zůstávaly v domácnosti, kdo byl dětem ochoten pomoci. Paní Věra (1947) poukazovala na to, že tehdy nikomu nepřipadala pomoc v podstatě cizích lidí zvláštní nebo nějakým způsobem nebezpečná: (...) Jako já si pamatuju, že my prostě v tom baráku, (...) když to některý dítě něco potřebovalo, tak automaticky, když přišlo, když zazvonilo na kohokoliv prostě, tak se $k$ nëmu chovalo jako $k$ vlastnímu, všichni. (...) Nebyl rozdíl mezi jednou rodinou, druhou rodinou. Paní Jana (1969) vzpomínala na to, že sousedská výpomoc fungovala podobně i v době dětství jejích dětí: (...) Jo, když holky vlastně byly malý, tak tady vedle bydleli Skořepovi, takže vlastně navzájem stejnè velký děti, navzájem jsme si je hlídali, když bylo potřeba, tak to si myslím, že jako jo. Že se znali, že to bylo vlastně tady jako sousedi, tak jako takovej bližší vztah tady byl jako, jo.

Zatímco ve výše uvedené výpovědi paní Rủženy vidíme reflexi strachu okolí o děti a přijetí tohoto strachu („to není žádná legrace“), paní Alena uznávala, že dnes je větší strach o děti do určité míry opodstatněný („taky a ta doba byla bezpečná“), nicméně z jejího vyprávění je cítit, že je možná tento strach až přehnaný („,úzkostliví rodiče“) a jeho dopady na děti omezují jejich volnost (,je to hodně utaženýc), kterou děti podle názoru paní Aleny potřebují. Určitou míru nebezpečí, které by podle názoru dotazovaných žen ještě za dětství jejich vlastních dětí nehrozilo (přepadení, bezdomovci na ulicích apod.), však dotazované ženy připouštěly. Např́klad samostatné cestování dětí autobusem bylo běžné v době jejich dětství stejně jako v době dětství jejich vlastních dětí. Paní Rủžena (1939) vzpomínala na své cestování v dětství: To už jsem (...) autobusem sama, že jo, měla jsem takovej kufříček a $v$ tom panenku a todleto všecko (...). Paní Věra (1947) $\mathrm{k}$ tématu dodávala: (...) Nebo ty děcka, aby pustili takhle večír v tomhle věku, si myslím, to vůbec nepřichází v úvahu. A je fakt, že s tím jako já souhlasím v dnešní době, jaká je, že jo, ale tehdá mě nenapadlo, že když pojede (pozn. dcera) po tý tmě, že by se mohlo něco... (pozn. stát).

Podle paní Věry (1947) mohl být pocit strachu o děti možnou př́činou zvýšení poptávky matek po babičkovské péči o vnoučata: No, já si myslím, že to je teda opravdu touhle dobou. Že by to možná třeba ani nebylo potřeba, že jo, kdyby ten režim nebo ten svět byl úplně jinačí, jako bejvával. Nepamatuju, že by někdy někoho přepadli (...) Nepamatuju si, že by mně mamka řekla, abych se s nikým nebavila třeba, jo, (...). Abych se s nima nebavila, jako ted' ríkám: „Nebav se s nikým, nezapojuj... “To jako ze svého dětství... by mě v životě nikdy nenapadlo, abych se nebavila. Když nékdo nèco chtěl vèdět, tak automaticky jsem mu všechno řekla, dá se říct. I tomu cizímu člověku. A neměla jsem tu představu, že by mě zneužil 
nebo prostě došlo $k$ něčemu takovýmu, no. Dříve, když podle dotazovaných žen nebyl pocit strachu o děti vnímán tak palčivě, nebyl podle žen důvod $\mathrm{k}$ tomu, aby rodiče $\mathrm{v}$ době, $\mathrm{kdy}$ byli v práci, zajištovali pro děti nějaké hlídání (pokud je ponechána stranou péče o nejmenší děti). Paní Marie (1951) vzpomínala na dobu svého dětství: (...) No tak tenkrát ani ty družiny nebyly, že jo. Já ani nevím, no. Ty děti byly samy doma. Kamarádka ta... ty rodiče pracovali ve městě, tak ona přišla ze školy a prostě tam sama se nějak tak musela o sebe starat nebo jsme různě chodily. Vyprávění paní Aleny (1952) ilustruje př́ípady, kdy se o děti starali jejich starší sourozenci: (...) když chodila (pozn. nejmladší sestra) do školky, tak jsme ji vyzvedávaly my. Ségra ji tam vodila, protože ještě byla jako na základce na Dukle, a já už jsem jezdila na ekonomku, nebo chodila pěšky, protože jsme neměli penize kolikrát na to (smích), takže jsem musela pěšky, tak to bylo brzo, takže ségra to odnesla, že vlastně ji vodila do školky. Rodiny se tedy obracely na babičky často spiše s prosbou o hlídání dětí během letních prázdnin.

\section{Dopravní dostupnost: Strašně náročné cestování}

Při vzpomínání dotazovaných žen na cestování za babičkami vystupoval vcelku často faktor vzdálenosti mezi místy bydlišt babiček a vnoučat. Tento faktor také býval zásadní pro jejich vztah s babičkami. Vzdálenost pro dotazované ženy neznamenala čistě jen geografický údaj, ale chápaly ji spíše jako dopravní dostupnost. Tento problém ilustrovalo vyprávění paní Jaroslavy (1942): Tahle babička (...), s tou já jsem nebyla v takovém styku, to už bylo moc daleko pres těch pár vesnic. Co tedy bylo podle dotazovaných žen vzdálené, bylo pro ně ve své podstatě nesnadno dopravně dostupné. Důvodem bylo bud' to, že člověk neměl možnost se na konkrétní místo přepravit dopravním prostředkem (a musel jít alespoň nějakou část cesty pěšky), nebo to, že byla doprava na místo velmi náročná $\mathrm{z}$ hlediska počtu přestupů a času (čekání na návazné spoje apod.). Během dětství dotazovaných žen nebývalo obvyklé, jak uvedla i paní Hana, aby rodina vlastnila automobil. Pokud babička nežila v dochozí vzdálenosti od vnoučete, bývaly rodiny při cestování za babičkami odkázané na možnosti veřejné dopravy. Paní Alena (1952) vzpomínala: Byli jsme tam o prázdninách a pak určitě každých čtrnáct dnů. Ještě jsme jezdívaly s mamkou, jako děti jsme jezdívaly vlakem a to bylo teda taky strašně náročný, protože se muselo jet na Českou Třebovou, přestupovaly jsme někde v Litomyšli, tam jsme zas čekaly na něco, na autobus asi, no to bylo tak strašně náročný cestování do týhle oblasti. (...) a takže to se pamatuju, že jako kus jsme $v \check{d} d y c k y$ musely jit pěšky. (...) No tam (pozn. za druhou babičkou) jsme jezdily jenom na ty prázdniny, protože to byla dálka. My jsme měli pak Trabanta, to už jsem byla šestnáctiletá, a když jsme předtím jako děti tam jely, tak jsme jezdivaly vlakem, což bylo taky ri̊zný prestupování, protože do tý vesnice, že jo, to jsme musely čekat na autobus a ještě $i$ ten vlak... jsme musely někde do Veselí nad Moravou, tam jsme někde přestupovaly, no.

Faktor vzdálenosti se podle dotazovaných žen promítá do četnosti osobního kontaktu babiček a žen, potažmo pak do charakteru vztahu mezi oběma. Paní Hana (1959) uvedla: (...) ještě je to dobrý, když spolu... nebo když jsou pobliž ty vnoučata a babič̌ka, protože si dost na sebe zvyknou. Když jsou daleko, tak je to špatný. Vztahy s některými svými babičkami označovaly dotazované ženy jako ne př́liš blízké právě kvưli tomu, že vzdálenost jim $s$ babičkami neumožňovala častý osobní kontakt, někdy např́íklad jen jednou, dvakrát do roka. Paní Anna (1946) hodnotila svůj vztah k jedné z babiček takto: Ř́kám, tam nebylo nic 
s tou druhou ve zlém, ale prostě jsme tam jednak málo jezdili, takže jsem jí tolik nepoznala, takže bylo to takový... tenkrát jsme auto neměli, nic takovýho, takže jezdit vlakem a tam různě prestupovat a autobusama, to bylo náročný.

\section{Moderní technologie: Mobily, televize, počítače}

Vykonávání role babičky je podle vyprávění dotazovaných žen ovlivněno i rozvojem moderních technologií. Jako př́nosné pro naplňování babičkovské role vyvstalo z vyprávění dotazovaných žen využívání (mobilního) telefonu. Přestože některé babičky neměly ještě dlouho v dospělém věku vlastní (pevné) telefonní připojení, telefon obecně nebyl babičkami přijímán nijak negativně a přístroj pro telefonické spojení začlenily do svého života. Vzhledem k vykonávání babičkovské role bylo pro ženy telefonické spojení prospěšné, protože jim umožňovalo častý kontakt $s$ vnoučaty i v případě, že osobní kontakt nebyl možný. Tak tomu bylo např́klad i u paní Věry (1947): (...) takže vlastně my se dá říct, že jsme spojený (pozn. s vnučkou) dennodenně telefonem (...). Jinak se dotazované ženy stavěly $\mathrm{k}$ dalším moderním technologiím a médiím $\mathrm{v}$ souvislosti $\mathrm{s}$ vnoučaty spiše negativně. Moderní technologie (televize, tablety, chytré telefony) dotazované ženy viděly jako něco, u čeho děti stráví část volného času, který by vzhledem ke svému věku mohly využívat $\mathrm{k}$ vhodnějším volnočasovým aktivitám. Paní Jana (1969) k tomuto uvedla: (...) jako druhá babička, když jí (pozn. vnučce) koupili ve čtyrech letech tablet, tak jsem myslela, že vyskočím z kůže (smích). Jsem říkala babičce: „Ona neumí jezdit na kole, jo, ale hlavně že má tablet, "jo. Dotazované babičky většinou zastávaly názor, že v jejich trávení společného času s vnoučaty by měly moderní technologie zabírat jen omezené množství času, a snažily se s vnoučaty trávit čas aktivitami bez využití těchto médií. Paní Jana (1969) dodala: Já $j i ́$ (pozn. vnučce) teda taky dovolím pohádku, ale až večír, když jde ležet (...). Tam (pozn. u druhé babičky) může celej den sedět u televize. To já tohohle nejsem zastánce teda.

Média ani moderní technologie koneckonců nebyly ani součástí babičkovských vzorů dotazovaných žen. Jak uvedla paní Věra (1947), dnešní babičky neměly ve svém dětství ani televizní príijímače: (...) tak tehdá, to je fakt, my jsme neměli televizi. Když brácha si vydělal první penize, tak koupil televizi. Tak my jsme mèli televizi, vlastně když mně bylo nějakejch 19 rokư, jo, takže já pamatuju akorát, že jsme chodili na televizi, když něco bylo, jedny jediný měli v baráku, tak se tam všechny děti sešly a seděly jsme po zemi normálně a koukaly jsme na televizi jako. O zhruba dvacet let mladší paní Jana (1969) dodala: (...) já nevím, za mě... že jo, tak dneska jsou počitače, televize, dřiv to nebylo, že jo, ale my jsme dř́v měli povinnosti i doma, že jo. Jak rychlý je vývoj v oblasti moderních technologií dokládá vyprávění babičky Růženy. Ta hovořila o tom, jak svému vnukovi před usnutím vyprávěla a četla, zatímco jeho sestru, která je o deset let mladší než její bratr, zajímá spíše tablet: (...) vite, ono dneska je to jiný, když ten Lukáš tady spával, no tak jsme zpivali, četla jsem mu: „Babi, a ted’.., “pak jsem zjistila, že spí nebo něco, ale už to je jiný. Dneska maji tablet, Eliška má tablet jeden, druhej taky, jo, já nechci to ř́kat jako ve zlým, jo, holka šikovná.

\section{Přístup ke starým lidem: Dost nás odepisujou}

Dotazované ženy hovořily ve svých vyprávěních i o změně př́stupu společnosti ke starým lidem, což se svým způsobem dotýká i proměny prarodičovské role. Nabyté zkušenosti 
starších generací podle dotazovaných žen nejsou v centru zájmu generací mladších. Dnes je podle babiček upřednostňováno mládí a jeho schopnost poradit si s různými situacemi. Celkově se dnes podle názoru paní Růženy (1939) hledí na to, co přichází: Určitě jsou zas děti, který rádi si poslechnou, jak se vyrůstalo, ale myslím si, že už zas tolik ne, že zase se ty děti rádi věnujou tomu, co přrichází, takhle bych si to já myslela. (...) A dneska vưbec ještě, zase řeknu to obráceně, ke starším lidem je jinej prístup, víte? Ono se o tom i debatuje, že třeba ty jako zkušenosti... no a že ty firmy zas třeba rádi, jo... Ale já se tomu nedivím, protože ten vývin je i ten jako technickej a já nevím všelijakej, no, takže ty mladý zase si víc poraděj nebo todle, no, tak je to.

Dotazované ženy vzpomínaly, že dříve prarodiče předávaly vnoučatům rady a zkušenosti, vyprávěly jim, jak se žilo dříve a podobně. Paní Marie (1951) hovořila o tom, že v dětství rádi poslouchali vyprávění svých babiček: Ale my jsme hodně vlastně se takhle dozvěděly a jako zajímalo nás to i ty dèti to poslouchat od těch babiček. Prostě jak se žilo, co bylo a tak. Podle paní Aleny (1952) mohou prarodiče ukázat vnoučatům jiný pohled na věc a i přes změny přístupu ke starým lidem mají svým vnoučatům stále co nabídnout: (...) myslím si, že jo, že je potřeba (...) třeba i dalši generace, která se na to divá i trošku jinak jo. Oni nás dneska dost odepisujou ty starý lidi (smích), ale já si myslím, že jsme taky dưležitý (smích).

Spolu s jistým vnímaným upozad’ováním starých lidí v současné společnosti souvisí i vnímání žen sebe samotných jako babiček. Dotazované ženy se na svou roli babičky, která se s životní etapou stáří pojí, těšily. Například paní Jaroslava (1942) uvedla: Já jsem tak ráda se stala babičkou. Opravdu jsem byla ráda $z$ toho prvního vnoučete, jsem měla velikou radost. Některé z dotazovaných žen se své prarodičovské role nemohly dočkat. Například paní Anna (1946) se babičkou stala podle svých slov „až v padesáti“ letech: (...) já jsem furt čekala, protože jsem byla babička až v 50, jsem ř́kala, taky už mohli dř́v, ale furt se $k$ tomu nikdo nemél. Tak na vnoučata jsem se těšila. Z narození vnoučat měly dotazované ženy radost. Zároveň ovšem hovořily o ženách, které znaly ze svého okolí nebo byly dalšími babičkami jejich vnoučat, které se se svou rolí babičky nedovedly ztotožnit. Babičkovská role pro ně byla prŕliš spjata se stářím a dané ženy sebe samy ještě do této věkové kategorie neřadily. Paní Jana přibližovala postoj k babičkovské roli těchto žen: (...) třeba moje kolegyně, ta mně furt říká: „No, mně prijít ditě, že budu babičkou... “Třeba ta Ivana (pozn. druhá babička vnučky), ta byla docela dotčená, jí to vadilo, že bude babičkou. Přitom ona už je $v$ důchodu, je v podstatě starši a přesto jako jí to... tak jako... jí to vadí, že už je stará. Že je babička. Mně ne, já právě jsem naopak, já jsem se s tím chlubila, já jsem na to byla pyšná, že budu babička, jo.

\section{Přístup k dětem: Tenkrát se dětským světem lidi nezabývali}

Stejně jako se podle dotazovaných žen mění přístup společnosti ke starým lidem, mění se i prŕístup k dětem. V souvislosti s odbornými poznatky o dětech a dětství se dnes podle paní Aleny (1952) věnuje dětem čím dál větší pozornost - tomu, jak přemýšlejí, vnímají a prožívají okolní svět: (...) dneska díky tomu... já nevím vývoji, nebo díky tomu, co víme o tom, jak ty děti přemejšlej, dejme tomu, jo, tenkrát se tím ty lidi nezabejvali. Za mý babičky se tím nezabejvali, co si to dítě myslí nebo co prožívá, oni... ani je to nenapadlo, si myslím. Tak to už muselo asi bejt, aby tam bylo něco... já si myslím, že se tím jako... ne netrápily, 
samožrejmě, když by tam byl nějakej zdravotní problém nebo něco, tak to bylo něco jinýho, ale já si myslím, že je nebrali tak vážně, jako dneska se to bere, jo.

I po materiální stránce jsou podle názorů dotazovaných žen děti zabezpečené lépe, než byla jejich generace v době dětství. Z výpovědi paní Věry (1947) vyplynulo, že to může být až na škodu, protože generace dnešních dětí si prý nedovede věcí dostatečně vážit a nedovede je docenit: (...) ted', když to těmhle dětem, který prostě maj všechno, na co se podívaj... to prostě neexistovalo. Prostě co jsme méli, za to jsme byli štastný a taky jsme si toho teda vždycky vážili, podstatně víc, jak si vážej ted'teda všeho. Paní Růžena (1939) k problematice dodala: (...) ta Eliška, no tak to zase jsou děti, ona taky... ona v̌̌echno, no, má, že jo, zas ř́kám: „Marto, ale jsou věci, který třeba... nespěchejte to... s tím, vždyt’zase už za chvíli jí to nebaví, "ale ona zas to Martina prodá, že jo, zase je o to zájem a tak dále. S ohledem na obecné znalosti a vědomosti je ale podle paní Růženy (1939) nejmladší generace vyspělejší, než dřívější generace podobného věku: Jo, třeba když něco odposlouchají (...), je znát, že to je takový vyspělejší. Už i mezi těma... ty... mezi sebou si ty děti leccos řeknou a tak, že jo.

Z hlediska běžného obstarání sebe sama a zapojení se do domácích prací je na tom však podle názoru paní Věry (1947) současná generace o něco hưře než generace předešlé: Říkám, nedej pán bůh, aby se opravdu někdy tý rodině něco stalo a ty rodiče zemřeli třeba, dneska při těch automobilových nehodách, že jo, je to možný kdykoliv kdekoliv, takže ty děcka by se těžko stavěly na vlastní nohy teda. Jeden vedle druhýho, si myslím. Že jsou na ty rodiče tak fixovaný, že jako ta samostatnost tady moc není. Paní Hana (1959) poukazovala na to, že oproti současné generaci mívaly děti v domácnosti své povinnosti, které musely plnit: Protože já jsem vlastně od 12 let myla okna, převlíkala a tak dále. Mamka chodila do obchodu, chodila od rána do večera, takže prakticky jsme todleto my v̌̌echno dělali, jo.

Proměna přístupu k dětem se přímo dotkla i prarodičovské role. Cílem generace babiček dotazovaných žen bylo podle jejich vyprávění především zabezpečení vnoučete. Babičky tehdejší generace dětem zajištovaly stravu a zpovzdálí dohlížely na to, aby se jim nic nestalo. Současná generace babiček se už zaměřuje v prvé řadě na to, jak a čím budou společně s vnoučetem trávit čas a jaké aktivity pro své vnouče připraví. Tuto proměnu ilustruje paní Jaroslava (1942): To, co se děje ted', že se těm dětem věnujeme jako a vymýślíme, co by oni, tak to nebylo, to neexistovalo. To ty děti běhaly venku po tý ulici, než teda šly do školy samozřejmě, a tvořily samy si nějaké hry, nějaké zábavy. Tam žádnej dospělej nebyl, kdo by jim organizoval, co mají dělat. Zřejmě v souvislosti s materiálním zajištěním vnoučat, o kterém dotazované ženy hovořily, se pro babičky stalo zcela samozřejmé obdarovávat při různých příležitostech svá vnoučata.

\section{Závěr a diskuse}

Předkládaná studie se na prríkladu babičkovské role snažila předvést, jakým způsobem může společnost ovlivnit rodinné role, které jsou obecně spjaté s rozvolněnějšími rolovými předpisy. K osvětlení této problematiky byla využita historicko-sociologická perspektiva, v níž se mohou projevit i málo viditelné či uvědomované společenské vlivy. Analyzovány byly rozhovory s ženami, současnými babičkami, které reflektovaly roli babičky posledních tří generací. Ženy, jež měly s rolí osobní zkušenosti z pozice vnoučete, rodiče dítěte i samotné babičky, mohou nejlépe reflektovat proměny této role a poukázat na faktory, které ji v jejich očích utvářejí. 
Některé soudobé výzkumy poukazují na absenci jednotných norem spojených s rolí babičky [např. Hasmanová Marhánková 2015]. Dotazované ženy však poukazovaly na tlak faktorů ovlivňujících jejich vykonávání babičkovské role, které samy nemohou ovlivnit a s kterými se vzhledem k rychlosti a významnosti proměn v některých společenských oblastech musejí samy vyrovnat. Vzory babiček, se kterými se během svého života setkaly, jim pro uchopení role v soudobém společenském rámci nestačí. Odpozorované pojetí role vlastní babičky nelze jednoduše „zkopírovat“. Tato skutečnost poukazuje na existenci určitého na první pohled možná ne zcela patrného rámce. Tento rámec ovšem podle názoru dotazovaných žen vcelku výrazně formuje možnosti individuálního pojetí babičkovské role a během posledních tří generací rodin dotazovaných žen zaznamenal výrazné proměny. Ačkoliv tedy některé výzkumy hovoří o rozvolněných předpisech babičkovské role, tato role se stále musí držet v mezích společenského rámce. Jisté společné charakteristiky soudobé babičkovské role proto lze nalézt.

V porovnání s předchozími generacemi došlo podle dotazovaných žen vlivem proměny některých společenských faktorů $\mathrm{k}$ těmto změnám $\mathrm{v}$ obecném rámci pro vykonávání babičkovské role: společně trávený čas babiček a dětí je omezen (pracovní povinnosti babiček, časová vytíženost babiček); došlo k zintenzivnění poptávky po péči babiček (zaměstnání matek, strach o děti); současné babičky mají méně sil pro vykonávání své role (odkládání rodičovství); mění se obsah role samotné (př́istup ke starým lidem, přístup $\mathrm{k}$ dětem); možnost kontaktu babiček a vnoučat je velmi usnadněna (dopravní dostupnost, moderní technologie).

Oproti dřívějším generacím babiček se současným babičkám velmi rozšířily možnosti kontaktu s vnoučaty a tím i možnosti navázání blízkého vztahu. Telefonické spojení i osobní návštěvy umožněné výrazným rozšířením osobní přepravy daly ženám př́ležitost k vytvoření blízkého vztahu s vnoučaty. U dotazovaných žen naopak zapříčinil omezený kontakt způsobený špatnou dopravní dostupností a absencí telefonického spojení ochladlé vztahy s jejich vlastními babičkami, které nežily poblíž a nebylo možné se s nimi častěji vídat a více se poznávat.

Výrazně pozitivní proměna dopravní dostupnosti je však provázena negativními proměnami jiných společenských faktorů. Podle dotazovaných žen jsou omezeny možnosti realizování jejich vlastních představ o vykonávání babičkovské role v důsledku jejich časové vytíženosti. Zaměstnání a posunutí věku odchodu do důchodu oproti dřívějším generacím, péče o své staré rodiče či sourozence, kterou současně s péčí o vnoučata dřívější generace babiček podle dotazovaných žen nepoznaly, a do jisté míry i nárůst osobních a volnočasových aktivit zpo̊sobily nedostatek času na vnoučata. Do již tak napjatého časového rozvrhu zejména pracujících babiček vstupují některé matky s novým požadavkem na intenzivní zapojení babiček do péče o vnoučata z pracovních důvodů i kvůli obavám o bezpečí svých dětí. Vzhledem k věku babiček, zapřričiněném i soudobým odkládáním rodičovství do pozdějšího věku, to pro ně občas bývá náročné.

Změnou přístupu ke starým lidem a zároveň i změnou přístupu $\mathrm{k}$ dětem došlo podle dotazovaných žen k proměně obsahu babičkovské role. Zkušenosti starých lidí jsou dnes mladšími generacemi upozad’ovány a současně se oproti dřívějším generacím věnuje mnohem více pozornosti dětem a dětskému světu. Namísto předávání zkušeností a vědomostí vnoučatům tak dnes babičky spíše vymýšlejí dětem společný program, zábavu a dárky k různým př́ležitostem. 
Studie ukázala, že historicko-sociologický pohled je pro porozumění soudobému vykonávání role babičky př́nosný. Pomáhá lépe pochopit situaci, ve které dnešní ženy vstupují do role babičky, a nahlédnout tak do pozadí některých problémů, které dnešní ženy v roli babičky musejí řšsit. Poukazuje také na rozdíly v možnostech uchopení babičkovské role oproti dřívějším generacím.

Některé výzkumy hovoří o rolovém přetížení dnešních babiček [např. Vidovićová Galčanová - Petrová Kafková 2015]. Nabízí se také otázka, zda nedošlo vzhledem k požadavkům, které jsou dnes na roli babičky kladeny, k přetížení samotné babičkovské role. Zda v některých př́ípadech nedochází k částečnému suplování role rodiče z důvodu usnadnění kombinace rodinného a pracovního života matky, $z$ důvodu všeobecné snahy zajistit dětem maximum dozoru $\mathrm{v}$ dnešní ne zcela bezpečné době a $\mathrm{z}$ důvodu zajistit dětem po celý čas maximum zábavy a aktivit. To vše $\mathrm{v}$ situaci, kdy jsou na rozdíl od dřívějších dob mnohdy bydliště babiček a vnoučat oddělená, kdy se zvyšuje věk žen vstupujících do role babičky a mají proto méně energie, než mívaly jejich babičky a matky v prarodičovské roli, a kdy jsou některé z babiček ještě pracující ženy.

Realizovaný výzkum se týkal městských dětí a účastnily se ho babičky, které žily v dojezdové vzdálenosti od svých vnoučat (do jedné hodiny cesty). Zajímavé by bylo srovnání reflexe společenských faktorů a výsledného společenského rámce typicky venkovského vzorku participantů: dětí žijících v menších venkovských obcích a jejich blízkých babiček.

\section{Bibliografie}

Bhopal, Kalwant - Brannen, Julia - Heptinstall, Ellen [2000]. The importance of grandparents, relatives, friends and others. In. Bhopal, Kalwant - Brannen, Julia - Heptinstall, Ellen. Connecting Children: Care and Family Life in Later Childhood. London, New York: RoutledgeFalmer, s. 130-153.

Davies, Hayley [2011]. Affinities, seeing and feeling like family: Exploring why children value face-to-face contact. Childhood 19 (1): 8-23.

Gauthier, Anne [2002]. The Role of Grandparents. Current Sociology 50 (2): 295-307.

Gratton, Brian - Haber, Carole [1996]. Three Phases in the History of American Grandparents: Authority, Burden, Companion. Generations 20: 7-12.

Harper, Sarah - Smith, Peter K. - Hagestad, Gunhild O. [2010]. Introduction. Editorial and Introduction. Journal of Intergenerational Relationships 8: 207-218.

Hasmanová Marhánková, Jaroslava [2015]. „Být dobrou babičkou“ - normativní očekávání spojená s rolí babička v současné české rodině. Sociologický časopis 51 (5): 737-760.

Hasmanová Marhánková, Jaroslava - Štípková, Martina [2014]. Typologie prarodičovství v české společnosti - faktory ovlivňující zapojení prarodičů do péče o vnoučata. Naše společnost 1: 15-26.

Hurme, Helena - Westerback, Susanne - Quadrello, Tatiana [2010]. Traditional and New Forms of Contact between Grandparents and Grandchildren. Journal of Intergenerational Relationships 8: 264-280.

Cherlin, Andrew J. - Furstenberg, Frank F. [1986]. New American Grandparent: A Place in the Family, A Life Apart. Cambridge, MA, USA: Harvard University Press, s. 24-51.

Kahana, Boaz - Kahana, Eva [1970]. Grandparenthood from the Perspective of the Developing Grandchild. Developmental Psychology 3 (1): 98-105.

Kemp, Candace L. [2007]. Grandparent - Grandchild Ties. Reflections on Continuity and Change across Three Generations. Journal of Family Issues 28: 855-881.

Koutná Kostínková, Jana - Čermák, Ivo [2013]. Interpretativní fenomenologická analýza. In. Řiháček, Tomáš - Čermák, Ivo - Hytych, Roman. Kvalitativní analýza texti̊: čtyři př́stupy. Brno: Masarykova univerzita, s. 9-43. 
Quadrello, Tatiana - Hurme, Helena - Menzinger, Juliana - Smith, Peter K. - Veisson, Marika - Vidal, S. - Westerback, Susanne [2005]. Grandparents use of new communication technologies in a European perspective. European Journal of Ageing 2: 200-207.

Sandel, Todd L. - Cho, Grace E. - Miller, Peggy J. - Wang, Su-hua [2006]. What It Means to be a Grandmother: A Cross-Cultural Study of Taiwanese and Euro-American Grandmothers' Beliefs. The Journal of Family Communication 6 (4): 255-278.

Souralová, Adéla [2015]. „Můžeš prostě říct, že máš babičku“: Vietnamské děti, české babičky a význam prarodičovství v jejich biografiích. Sociologický časopis 51(5): 815-844.

Uhlenberg, Peter [2004]. Historical Forces Shaping Grandparent-Grandchild Relationships: Demography and Beyond. In. Silverstein, M. (ed). Annual Review of Gerontology and Geriatrics, 24: Intergenerational Relations across Time and Place. New York: Springer Publishing Company, s. 77-97.

Urban, Lukáš [2011]. Sociologie trochu jinak. 2. vyd. Praha: Grada Publishing.

Vidovićová, Lucie - Galčanová, Lucie - Petrová Kafková, Marcela [2015]. Význam a obsah prarodičovské role u mladých českých seniorů a seniorek. Sociologický časopis 51 (5): 761-782.

Tereza Čepilová $\left({ }^{\star} 1990\right)$ je doktorandkou Pracoviště oboru Historická sociologie na Fakultě humanitních studií Univerzity Karlovy v Praze. Odbornými oblastmi zájmu autorky jsou rodinné vztahy, dětská kultura a volný čas předškoláků a školáki̊. 